\title{
Studi desain Taman Tebet sebagai youth park
}

\author{
Aprianto Dwi Putra ${ }^{1}$, Naniek Kohdrata1* ${ }^{1 *}$ Gusti Alit Gunadi² \\ 1. Program Studi Arsitektur Pertamanan, Fakultas Pertanian, Universitas Udayana, Indonesia \\ 2. Program Studi Agroekoteknologi, Fakultas Pertanian, Universitas Udayana, Indonesia \\ *E-mail: naniek_kohdrata@unud.ac.id
}

\begin{abstract}
Design study of Taman Tebet as youth park. Jakarta's green open spaces should have functional value to fulfill the need of heterogeneous people of Jakarta for open public spaces. The absence of character in most of Jakarta's city parks is underpinning this research. This research's objective is to illustrate the character of Jakarta's city park by creating a design concept that fit with current Jakarta's people needs. The research methods are inventory, analysis, synthesis, concept to design stage. The result of this research is a concept of design that can depict Jakarta city park character today, by applying contemporary landscape elements. The existing design concept will be complemented with design development to strengthen the characteristic of the park. The end products of this research are the design concept, concept of space, concept of circulation, the green layout concept, site plan, and transformation of certain object shape which will be specially displayed. As a conclusion, Youth Park design concept is able to bring a new characters in the park of Jakarta in general and can meet the needs of public space Jakarta now.
\end{abstract}

Keywords: contemporary landscape, Taman Tebet, youth park

\section{Pendahuluan}

Jakarta merupakan ibu kota Negara Indonesia dengan luas wilayah berupa daratan $662,33 \mathrm{~km}^{2}$ dan berupa lautan 6.977,5 km² (SK Gubernur, 2007). Menurut Badan Pusat Statistik (2016), jumlah penduduk DKI Jakarta sebesar 10.177.924 jiwa dengan pertumbuhan penduduk per tahun sebesar 1,02\%. Sebagai ibukota negara dengan berbagai aktivitas, menjadikan Jakarta terus dipenuhi pendatang. Hal ini membuat semakin tinggi arus urbanisasi dan berkurangnya jumlah ruang terbuka hijau kota akibat kebutuhan tempat tinggal yang harus dipenuhi. Ruang terbuka hijau Kota Jakarta harus dapat memiliki nilai ekologis, nilai sosial budaya, nilai estetika serta harus bersifat fungsional untuk memenuhi kebutuhan masyarakat Jakarta yang sangat heterogen.

Belum ada karakter atau ciri khusus pada sebagian besar taman di Jakarta melandasi dibuatnya konsep desain yang dapat menggambarkan karakter taman di Jakarta. Konsep ini dibuat untuk dapat mengoptimalkan nilai fungsi taman sesuai kebutuhan pengguna. Konsep Youth Park dapat menggambarkan kebutuhan ruang terbuka masyarakat Jakarta secara umum. Hal ini dilandasi oleh mobilitas masyarakat yang tinggi dan berbagai kegiatan unik masyarakat Jakarta yang dinamis. Berbagai kegiatan ini harus dapat disalurkan menjadi kegiatan yang positif seperti dengan membuat ruang ekspresi, ruang rekreasi, ruang sosialisasi hingga ruang edukasi sebagai fasilitas pendukung. Upaya ini dilakukan untuk mencegah terjadinya kegiatan negatif yang bersifat kriminalitas seperti tawuran antar kelompok yang sering kali terjadi di kalangan masyarakat Jakarta.

Rumusan masalah yang diangkat adalah belum adanya karakter pada sebagian besar taman Kota Jakarta yang dapat memenuhi kebutuhan ruang terbuka masyarakat Jakarta secara umum. Tujuan penelitian ini yaitu menggambarkan karakter taman Kota Jakarta dengan membuat konsep desain yang sesuai dengan kebutuhan ruang terbuka masyarakat Jakarta secara umum. 


\section{Metodologi}

\subsection{Tempat dan Waktu Penelitian}

Penelitian ini berlokasi di Taman Tebet, Kota Administrasi Jakarta Selatan, Provinsi DKI Jakarta (Gambar 1). Penelitian dilakukan dalam kurun waktu tujuh bulan dimulai dari Januari hingga Agustus 2017.

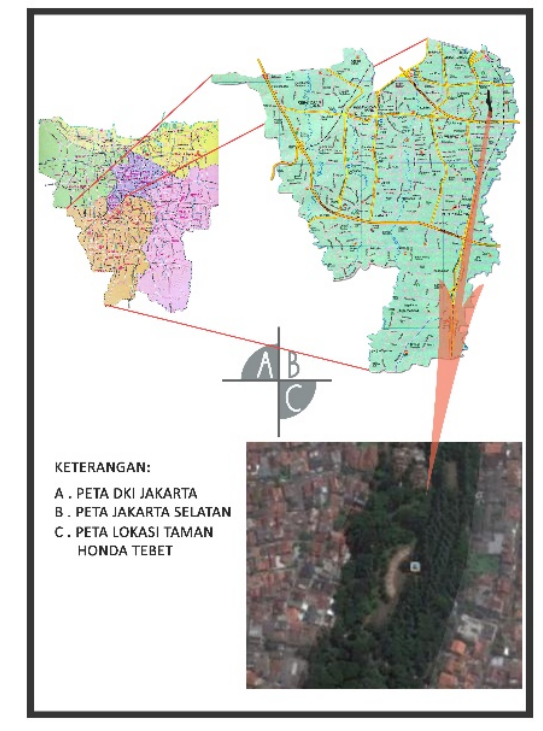

Gambar 1. Lokasi Penelitian

\subsection{Alat dan Bahan}

Alat yang digunakan dalam kegiatan penelitian ini berupa kamera digital, alat gambar, alat ukur, dan dibantu dengan software penunjang seperti Microsoft word, AutoCAD, SketchUp, Photoshop, dan Lumion. Bahan yang diperlukan adalah site plan Taman Tebet sebagai acuan, daftar pertanyaan untuk kegiatan wawancara serta data-data penunjang lain mengenai tapak.

\subsection{Metode Penelitian}

Metode penelitian yang digunakan mengacu pada metode Rachman, 1984 (dalam Putri, 2013) yang meliputi tahap inventarisasi, analisis, sintesis, konsep hingga perancangan.

\subsection{Batasan dan Hasil Studi}

Penelitian ini dibatasi hanya sampai tahap konsep desain. Hasil akhir produk desain lansekap ini berupa konsep ruang, konsep sirkulasi, konsep tata hijau, site plan, konsep desain serta perspektif beberapa objek yang akan ditampilkan secara khusus.

\section{Hasil dan Pembahasan \\ 3.1 Inventarisasi Tapak}

\subsubsection{Aspek Biofisik}

Taman Tebet memiliki luas tapak mencapai 2,3 Ha yang dikelilingi pagar pembatas dan tanaman peneduh. Terletak diantara Jalan Tebet Barat Raya dan Jalan Tebet Timur Raya, Jakarta Selatan menjadikan Taman Tebet cukup mudah diakses oleh masyarakat Jakarta secara umum. Kawasan taman terbelah oleh anak sungai yang mengalir dari arah Pasar Minggu menuju ke Manggarai. Lingkungan sekitar Taman Tebet merupakan daerah seperti studio musik, sekolah grafis, factory outlet, perkantoran hingga terdapat banyak cafe tempat berkumpul kaum muda.

Secara umum Jakarta Selatan merupakan dataran rendah dengan ketinggian rata-rata 26,2 m dpl (Jakarta Selatan Dalam Angka, 2015). Taman Tebet berada pada ketinggian 12,5 - $15 \mathrm{~m}$ dpl, dimana titik terendah terdapat pada area sekitar anak sungai dan titik tertinggi berada pada sisi bagian barat tapak. Kemiringan lahan Taman Tebet berkisar antara $2^{\circ}$ hingga $7^{\circ}$ masih dalam kategori kemiringan yang aman untuk 
aktivitas manusia. Suhu udara rata-rata Jakarta Selatan tahun 2015 adalah $27,6^{\circ} \mathrm{C}$ dengan kelembaban udara rata-rata 55\%. Curah hujan tertinggi terjadi pada bulan Januari yang mencapai $681,3 \mathrm{~mm}$ dan terendah terjadi pada bulan Oktober yaitu 26,8 mm (Jakarta Selatan Dalam Angka, 2015).

Sirkulasi kendaraan pada Taman Tebet sering kali terjadi kepadatan akibat penyempitan jalan karena pengguna taman yang parkir kendaraan di bahu jalan. Belum adanya area parkir khusus untuk pengguna taman menjadi penyebab utama terjadinya penyempitan Jalan Raya Tebet. Sumber air pada tapak berasal dari air tanah. Air tanah dipompa untuk kemudian didistribusikan sesuai peruntukkan yang berbeda seperti untuk penyiraman tanaman, kebutuhan toilet, hingga kebutuhan untuk ibadah. Jika sumber air utama tidak dapat digunakan, petugas menggunakan air sungai untuk kepentingan penyiraman tanaman.

Area hijau pada tapak cenderung dibiarkan alami sesuai keadaan awal yang sangat dipenuhi berbagai jenis vegetasi sehingga tapak sangat rimbun dan sejuk. Satwa yang terlihat pada Taman Tebet hanya kucing dan burung. Petugas dari Suku Dinas Kehutanan Jakarta Selatan juga memberlakukan aturan khusus untuk tidak membawa hewan ke dalam taman dengan alasan kebersihan. Sumber suara pada tapak cenderung didominasi oleh suara bising kendaraan bermotor yang melintasi sekitar taman.

Fasilitas yang ada berupa sarana olahraga, area bermain anak, toilet, ruang ibadah, tempat parkir sepeda, bench, dan area refleksi. Sementara utilitas yang terdapat pada taman berupa jaringan internet nirkabel (wifi), air minum dari PDAM, lampu penerangan serta perlistrikan lainnya. Keadaan lapangan futsal tidak termanfaatkan dengan baik. Perlu adanya peremajaan bentuk pada area tersebut. Lapangan bulu tangkis dan body workout bar berkeadaan baik dapat digunakan sesuai dengan peruntukannya. Ketiga area olahraga ini terletak berjauhan tidak pada lingkup area yang sama. Dapat jadi lebih menarik jika letak sarana olahraga berada dalam satu zona yang sama. Keadaan toilet terbilang kurang layak dari segi kebersihan dan dari segi jumlah. Fasilitas lain seperti ruang ibadah kurang layak pakai. Keadaan pelataran dan jogging track dalam keadaan cukup baik dan dapat dipergunakan sesuai dengan fungsinya masing-masing.

\subsubsection{Aspek Sosial}

Taman Tebet merupakan taman kota terbesar di wilayah Jakarta Selatan. Selain menjadi aktivitas olahraga dan rekreasi Taman Tebet juga direncanakan untuk dapat menghadirkan nilai edukasi dengan menghadirkan ruang baca terbuka. Kegiatan sosial yang pernah dilakukan di Taman Tebet salah satunya adalah Hidden Park pada tahun 2013. Kegiatan ini merupakan kampanye yang bertujuan untuk menghidupkan kembali sekaligus mengangkat potensi tersembunyi dari taman-taman di Jakarta dengan maksimal agar dapat dimanfaatkan sebagai ruang kreatif publik. Kegiatan ini didukung oleh Dinas Kehutanan Provinsi DKI Jakarta sebagai salah satu bentuk perluasan ruang terbuka hijau ibu kota.

\subsubsection{Demografi DKI Jakarta}

Jumlah penduduk DKI Jakarta berdasarkan proyeksi penduduk hasil sensus penduduk 2010 sebesar 10.177.924 jiwa yang terdiri dari suku Jawa $(35,1 \%)$, Sunda (15,2\%), Tionghoa $(5,5 \%)$, Batak $(3,6 \%)$, dan beberapa suku lainnya (BPS, 2016). Komposisi penganut agama di DKI Jakarta adalah Islam $(83,3 \%)$, Kristen Protestan (8,6\%), Katolik (4,4\%), Buddha (3,8\%), dan Hindu (1,2\%).

\subsection{Analisis dan Sintesis Tapak}

Mayoritas masyarakat Kota Jakarta kini cenderung hidup berkotak-kotak dan menjauh dari kegiatan interaksi sosial. Hal ini terjadi bukan tanpa alasan melainkan pengaruh budaya ruang publik Kota Jakarta yang terlalu berambisi membuat pembatas antar ruang. Prinsip ini cukup bertolak belakang dengan akar budaya Betawi yang nyablak atau ceplas-ceplos yang kemudian dapat diartikan apa adanya atau terbuka. Aksesibel atau keterbukaan ruang dapat menghadirkan kembali kebiasaan masyarakat tempo dulu dengan suasana yang sekarang. Berubah ke masa kini tanpa menghilangkan budaya lama yang memiliki manfaat baik. Ruang terbuka harus bersifat terbuka dan dinamis sehingga pergerakan dan kegiatan manusia pengguna terlihat aktif dalam menggunakan setiap ruang yang ada.

\subsubsection{Aspek Biofisik}

Taman Tebet memiliki luas 2,3 Ha yang terbagi menjadi area terbangun dan area hijau. Persentase area terbangun pada taman tidak lebih dari $30 \%$ dari luas keseluruhan area taman. Pengelompokan area pada taman akan dibagi kedalam beberapa zona sesuai dengan aktivitas dan fungsi dari masing-masing ruang yang ada. Berada pada kisaran ketinggian 12,5 - $15 \mathrm{~m}$ dpl menjadikan taman ini memiliki kontur yang unik dan variatif. Kemiringan lahan pada taman berkisar antara $2^{\circ}$ hingga 70 masih dalam kategori kemiringan lahan 
yang aman untuk aktivitas manusia. Keuntungan memiliki kemiringan lahan yang variatif ini dapat meminimalisir terjadinya banjir pada tapak serta dapat menjaga arah pandang dengan baik sehingga pengguna taman akan selalu melihat hijau-hijauan selama berada didalam taman. Suhu udara rata-rata Jakarta Selatan masih dalam batas kenyamanan untuk aktivitas manusia yaitu $27,6{ }^{\circ} \mathrm{C}$. Menurut Laurie (1986), standar suhu udara yang nyaman bagi manusia berada pada kisaran $23,5^{\circ} \mathrm{C}-30,5^{\circ} \mathrm{C}$. Penataan ulang dan penambahan jumlah vegetasi peneduh dapat menjadi solusi untuk memenuhi standar kenyamanan yang dibutuhkan manusia pengguna tapak.

Sisi barat taman merupakan pusat aktivitas yang terdapat bangunan berupa ruang ibadah, ruang jaga, toilet dan gudang. Ruang-ruang ini akan menjadi perhatian khusus untuk di desain agar tidak menjadi dominan dalam taman. Konsep desain yang dibuat harus berpihak pada lingkungan, hemat energi dan terlihat 'ringan'. Sirkulasi udara dalam ruangan harus dapat mengalir dengan baik dengan menerapkan sistem cross ventilation atau ventilasi silang. Sirkulasi kendaraan pada Taman Tebet sering kali terjadi kepadatan akibat penyempitan jalan karena pengguana taman yang parkir kendaraan dibahu jalan dan akibat adanya angkutan umum yang menurunkan dan menunggu penumpang di depan pintu masuk taman. Perlu dibuat area parkir kendaraan bermotor untuk mengurangi terjadinya kepadatan dan ketidakteraturan pada lingkungan sekeliling taman. Sirkulasi manusia pada taman berjalan dengan baik namun perlu dibuatkan akses sirkulasi yang lebih terbuka pada pintu masuk dan pintu keluar taman agar pengguna bisa mengakses area taman lebih mudah.

Kendala sistem perairan pada tapak menjadi salah satu masalah yang paling sering terjadi. Untuk meningkatkan suplai penyerapan air tanah, sebagian permukaan tanah yang tertutupi oleh paving dan perkerasan lainnya akan diubah dengan menggunakan material perkerasan yang tetap memiliki kemampuan menyerap air seperti paving block dengan jenis cellular grid. Selain dapat berperan menyerap air, penggunaan paving block ini juga memberikan kontribusi hijauan pada taman.

Taman Tebet terbagi menjadi sisi timur dan sisi barat. Sisi timur taman merupakan area rimbun yang dipenuhi oleh berbagai vegetasi peneduh dan dibiarkan tumbuh alami. Sisi barat merupakan pusat aktivitas pengguna sehingga lebih didominasi oleh tanaman hias dan tanaman peneduh yang indah secara visual. Pada sisi barat taman akan dilakukan perluasan view dengan membuka arah pandang ke sungai yang sebelumnya tertutupi. Perluasan view dilakukan untuk meningkatkan nilai estika dan nilai fungsi sungai serta memperluas dan menghadirkan atraksi baru pada taman. Untuk meredam kebisingan akan mengoptimalkan fungsi tanaman. Untuk menambah suasana alami dan tenang akan dihadirkan kolam di beberapa titik pada taman. Sarana olahraga pada taman akan dijadikan satu area yang sama dan dilakukan peremajaan sehingga dapat berfungsi dengan baik. Ruang ibadah akan di desain ulang agar selaras dengan konsep desain Youth Park. Taman Tebet juga akan menghadirkan ruang baca terbuka dipinggir anak sungai untuk menghadirkan atraksi baru pada taman serta menghadirkan suasana membaca yang baru.

\subsubsection{Aspek Sosial}

Mayoritas pengunjung Taman Tebet bertujuan untuk berkumpul komunitas dan olahraga. Dalam menunjang kebutuhan komunitas yang ada akan dibuatkan pembagian ruang untuk meningkatkan kenyamanan serta mempermudah akses bagi pengguna taman. Ruang-ruang pada taman akan terbagi kedalam beberapa zona diantaranya zona penerima, zona edukasi, zona rekreasi, zona olahraga, zona komersil, dan zona hijau.

Pada lingkungan sekitar taman khususnya pedestrian jalan banyak dimanfaatkan oleh pedagang untuk berjualan. Solusi yang dibuat adalah merelokasi pedagang dengan penataan tempat berjualan. Tempat yang akan disediakan untuk pedagang berada di dalam area parkir motor dengan view menghadap ke sungai. Pemberlakuan ini dapat meningkatkan nilai visual taman, tingkat kebesihan taman serta dapat meningkatkan nilai komersil.

\subsubsection{Demografi DKI Jakarta}

Penduduk DKI Jakarta di dominasi oleh suku Jawa, Betawi, dan Sunda. Ketiga suku ini cukup mempengaruhi kebudayaan dan pola hidup masyarakat Jakarta secara umum. Perbedaan latar belakang dan keberagaman masyarakat penduduk DKI Jakarta menggambarkan citra Kota Jakarta kini. Masyarakat yang heterogen, plural, dan multikultur menjadi ciri khas Kota Jakarta. Ciri khas ini kemudian diterapkan ke dalam konsep desain Taman Tebet sebagai Youth Park. 


\subsection{Konsep Desain}

Konsep desain Taman Tebet sebagai Youth Park merupakan konsep berdasarkan kebutuhan ruang terbuka publik Kota Jakarta dengan merangkum kebutuhan pengguna secara umum dan mengaplikasikan ke dalam tapak yang spesifik yaitu Taman Tebet. Konsep ini dibuat untuk mengembalikan pola masyarakat Jakarta tempo dulu yang dirasa memiliki manfaat baik untuk diterapkan di masa kini. Untuk memperkuat konsep ini harus dihadirkan beberapa faktor pendukung seperti ruang yang nyaman, area parkir memadai, akses berpihak terhadap difabel, hingga pelataran yang luas untuk kegiatan pagelaran kesenian ataupun kegiatan sosial yang dapat dinikmati masyarakat umum (Gambar 2).

\subsubsection{Interpretasi Konsep Desain}

Konsep desain akan terlihat pada bentuk ruang terbangun dan hardscape yang ada dalam tapak. Penerapan konsep juga dapat terlihat dalam menentukan ruang gerak kegiatan pengguna. Interpretasi konsep mencakup respon terhadap pengor youth Park yang modern, dan nilai fungsi yang baik.

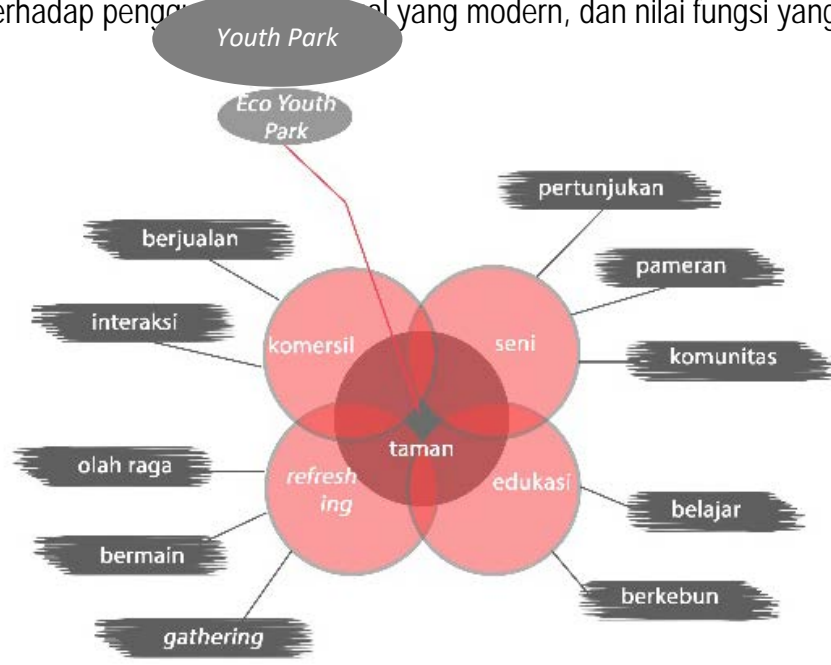

Gambar 2. Konsep Aktivitas Youth Park

\subsubsection{Konsep Ruang}

Pembagian ruang pada tapak perlu dilakukan untuk mempermudah akses pengguna dalam mengeksplorasi setiap ruang yang ada. Pembagaian ruang disesuaikan dengan fungsi masing-masing ruang sehingga tercipta zona-zona baru. Secara umum Taman Tebet dibagi kedalam enam zona yaitu zona penerima, zona rekreasi, zona edukasi, zona olahraga, zona komersil, dan zona hijau (Gambar 3).

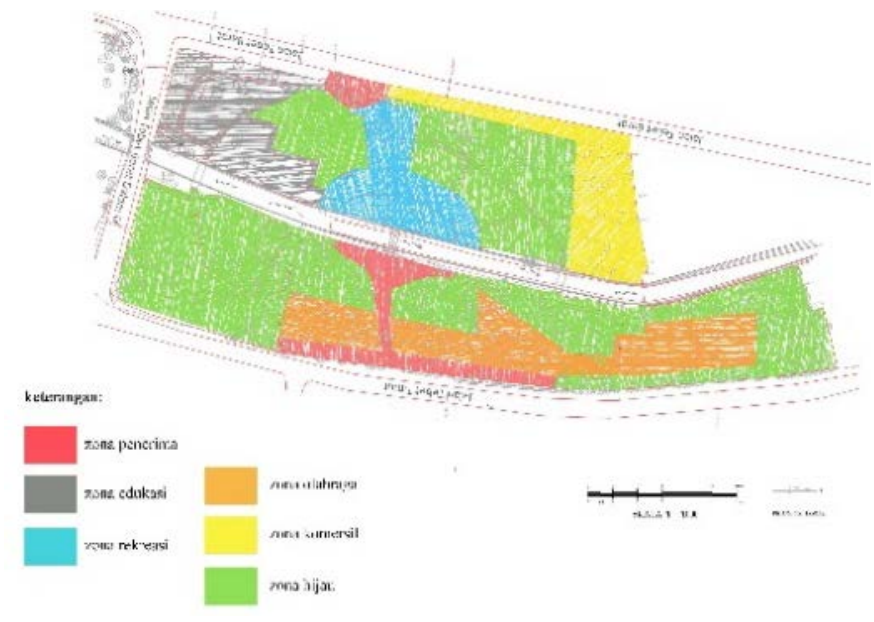

Gambar 3. Konsep Ruang Taman Tebet 


\subsubsection{Konsep Sirkulasi}

Sirkulasi dibagi menjadi dua, sirkulasi kendaraan dan sirkulasi manusia. Konsep sirkulasi berperan sangat penting dalam mengarahkan dan membatasi ruang gerak pengguna termasuk dampak yang akan terjadi pada lingkungan sekitar taman. Mengacu pada Booth (1983), Taman Tebet menerapkan pola sirkulasi casual dan controlled. Pola casual dihadirkan untuk memberikan kesan dinamis dan alami. Sementara pola controlled dipakai untuk mengatur sirkulasi kendaraan (Gambar 4a).

\subsubsection{Konsep Tata Hijau}

Konsep tata hijau terbagi menjadi tiga bagian yaitu tata hijau pencipta iklim mikro, tata hijau estetik, dan tata hijau edukasi (Gambar 4b).

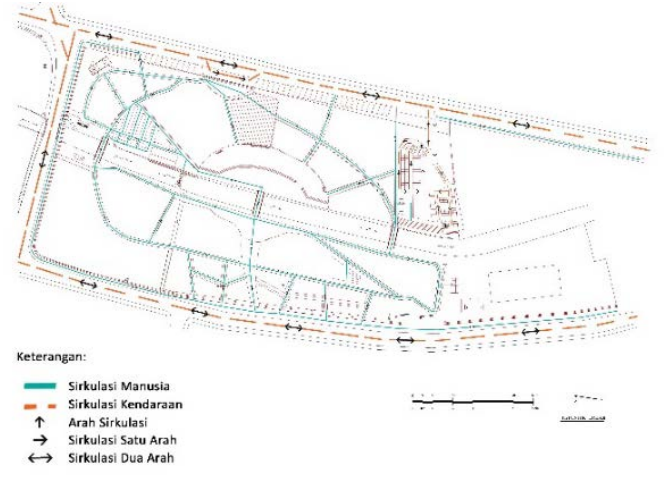

(a)

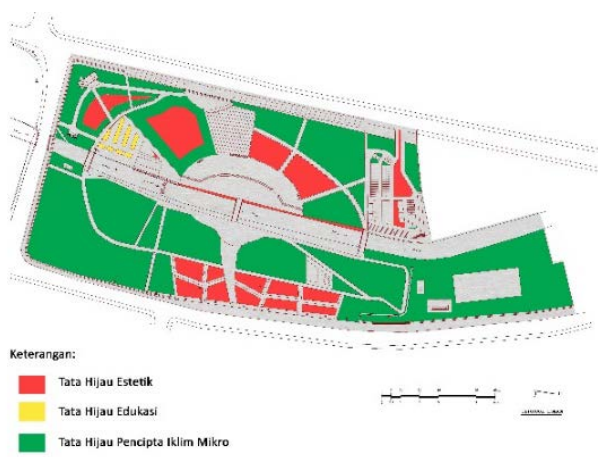

(b)

Gambar 4. Konsep Sirkulasi (a) dan Konsep Tata Hijau (b)

Konsep ini dibuat untuk memberikan kenyamanan pengguna taman. Penggunaan dan penempatan vegetasi pada taman dapat mempengaruhi tingkat kenyamanan sehingga harus disesuaikan dengan fungsi masing-masing ruang yang berkaitan langsung dengan vegetasi.

\subsection{Pengembangan Desain}

Pengembangan desain merupakan detail dari konsep desain yang telah dibuat. Pengembangan desain yang dimaksud meliputi pengaruh karakter pengguna terhadap bentuk, hubungan bentuk dengan keadaan sekitar tapak, dan bentukan yang tercipta dari karakter pengguna tapak.

\subsubsection{Pengaruh Karakter Pengguna Terhadap Bentuk}

Secara umum masyarakat Jakarta memiliki karakter yang unik seperti semangat yang tinggi, rasa ingin tahu yang besar, pola hidup yang dinamis, sikap berani, dan memiliki rasa yang tidak pernah puas. Secara khusus karakter masyarakat muda Jakarta yang akan diambil dan diterapkan pada pengembangan desain adalah semangat, rasa ingin tahu, dinamis, berani, dan percaya diri. Mengacu pada Hidayat (2016), garis-garis yang terbentuk dari karakter pengguna akan menjadi dasar dalam membuat suatu bentuk pada taman.

\subsubsection{Hubungan Bentuk dengan Keadaan Sekitar Tapak}

Bentuk yang tercipta merupakan gabungan dari beberapa bentuk bangunan di sekitar tapak. Bentuk tersebut akan dijadikan dasar dalam membuat area terbangun yang perlu dihadirkan seperti ruang ibadah, ruang baca, dan toilet. Bentuk tersebut akan diterapkan dalam desain Taman Tebet sehingga menyatu dengan lingkungan sekitar.

\subsubsection{Bentukan dari Karakter Pengguna}

Pengembangan desain ini menghasilkan bentuk baru yang dipengaruhi oleh karakter pengguna dari beberapa taman di Jakarta. Bentukan dari karakter pengguna taman yang ada menghasilkan site plan baru untuk Taman Tebet (Gambar 5). 


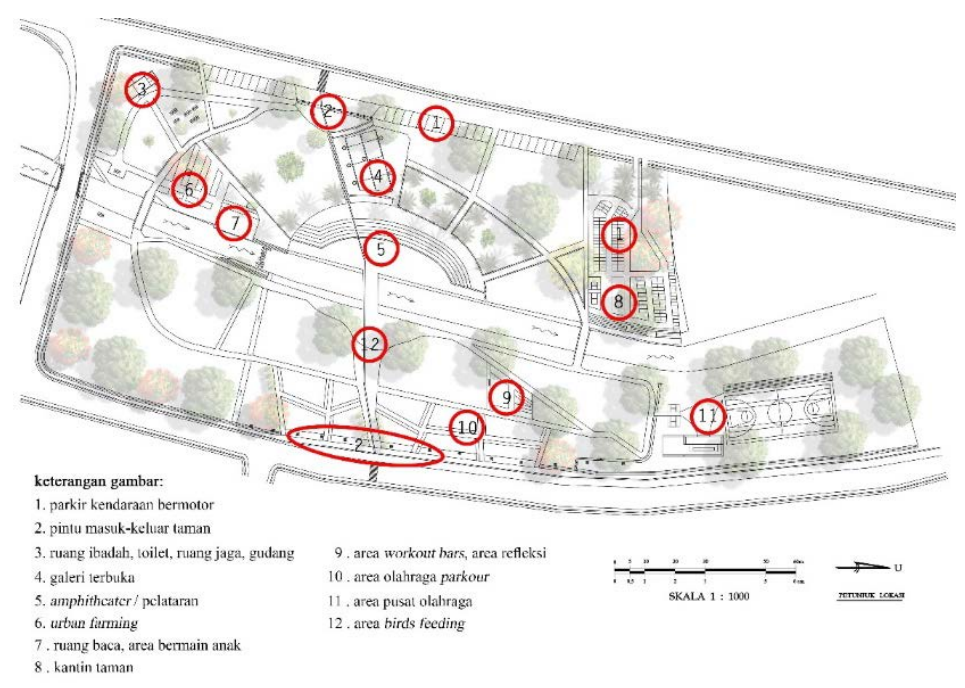

Gambar 5. Site Plan Taman Tebet

Pada beberapa titik bagian taman akan dihadirkan desain khusus sebagai icon atau ciri khas pada taman. Desain khusus ini menerapkan transformasi bentuk dari lingkungan sekitar untuk memberikan kesan alami. Bagian yang akan mengaplikasikan transformasi bentuk diantaranya ruang ibadah (Gambar 6), ruang baca dan galeri terbuka (Gambar 7), bangku taman (Gambar 8), dan area parkour dan pintu masuk sisi timur taman (Gambar 9).

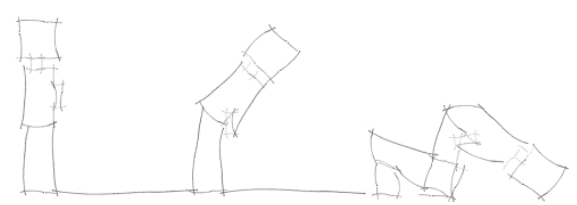

Berdrt RURU

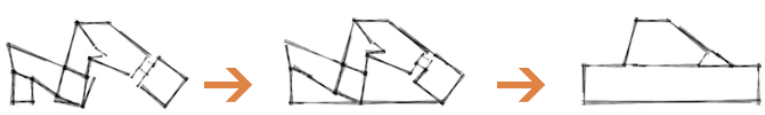

GERAKAN SHOLAT, SUJUD

Gambar 6. Transformasi Bentuk Ruang Ibadah

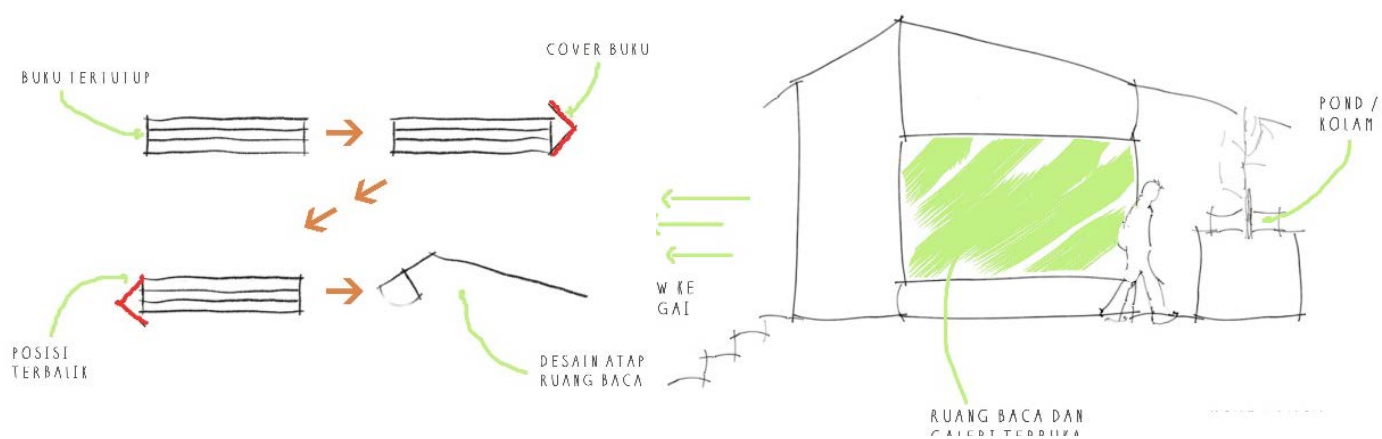

Gambar 7. Transformasi Bentuk Ruang Baca dan Galeri Terbuka 


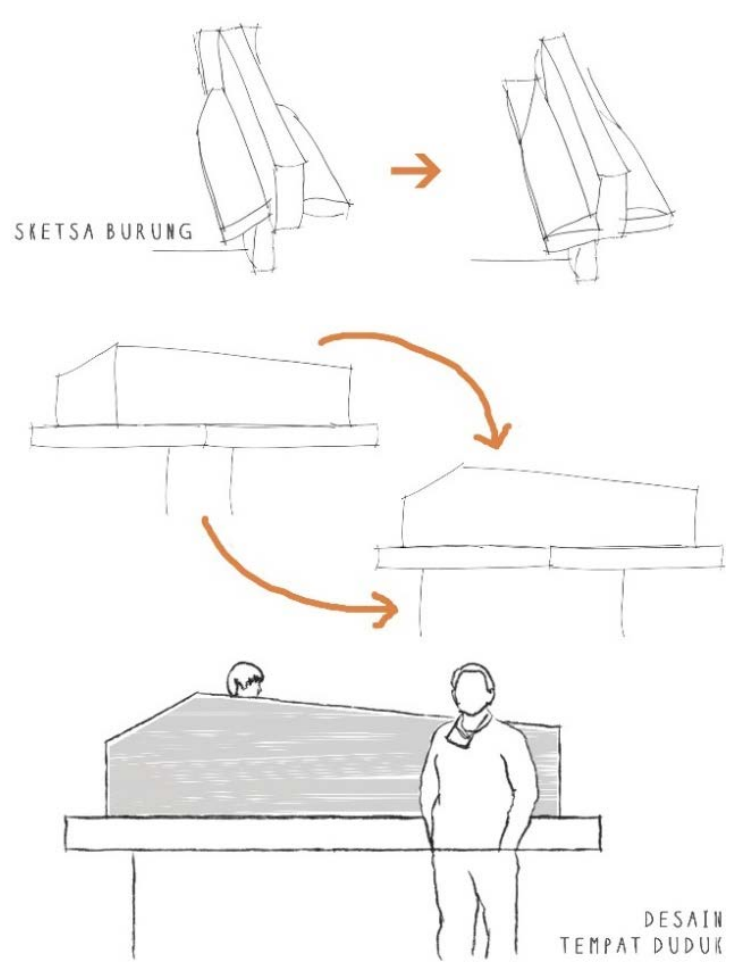

Gambar 8. Transformasi Bentuk Bench

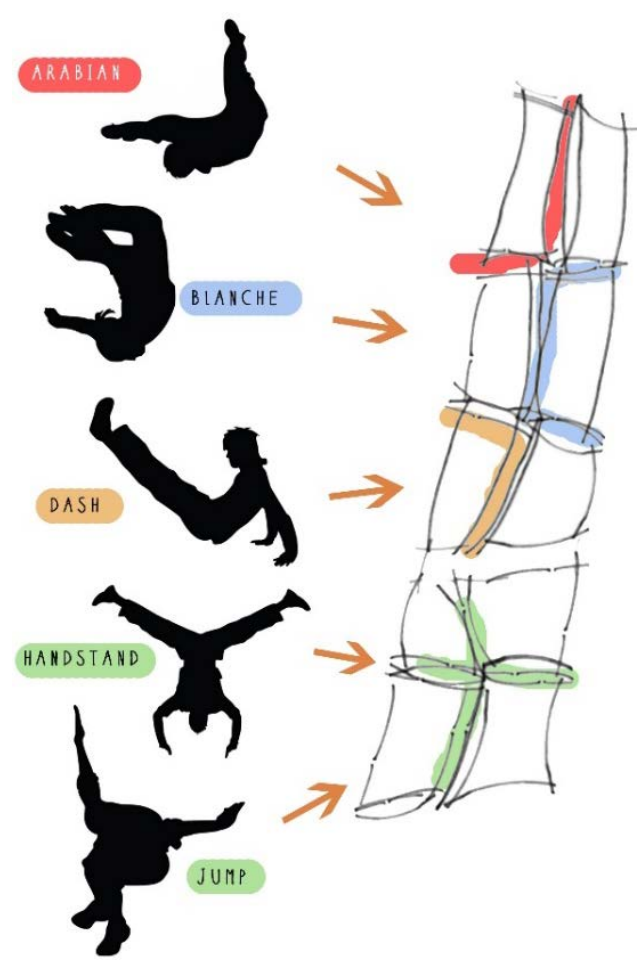

Gambar 9. Transformasi Bentuk Parkour and Entrance Zone

\section{Simpulan dan Saran}

\subsection{Simpulan}

Studi Desain Taman Tebet sebagai Youth Park merupakan konsep untuk meningkatkan nilai fungsi pada taman. Konsep Youth Park dapat menghadirkan karakter baru pada taman di Jakarta secara umum serta dapat memenuhi kebutuhan ruang terbuka publik masyarakat Jakarta kini. Taman Tebet kemudian dibagi ke dalam beberapa zona dengan tujuan untuk mempermudah pengguna dalam mengeksplorasi setiap ruang. Konsep sirkulasi Taman Tebet menerapkan pola sirkulasi casual dan controlled. Konsep tata hijau dibagi menjadi tiga bagian yaitu tata hijau pencipta iklim mikro, tata hijau estetik, dan tata hijau edukasi.

Pengembangan desain dibuat untuk memperkuat karakter taman dengan mengekspos beberapa objek yang ditampilkan secara khusus. Objek yang dimaksud berupa ruang ibadah, ruang baca dan galeri terbuka, bangku taman (bench), parkour and entrance zone, dan rumah burung. Hasil dari konsep desain dan pengembangan desain Taman Tebet berupa konsep ruang, konsep sirkulasi, konsep tata hijau, site plan hingga transformasi bentuk untuk beberapa objek yang ingin ditampilkan secara khusus.

\subsection{Saran}

Hasil penelitian ini diharapkan mampu menggambarkan karakter taman di Jakarta secara umum sesuai kebutuhan akan ruang terbuka publik masyarakat Jakarta kini. Konsep desain ini dapat dijadikan sebagai referensi atau bahan pertimbangan terhadap penelitian sejenis.

\section{Daftar Pustaka}

Booth, N. K. 1983. Basic Elements of Landscape Architectural Design. USA: Waveland Press.

BPS. 2015. Jakarta Selatan Dalam Angka Tahun 2015. Badan Pusat Statistik Kota Administrasi Jakarta Selatan. Jakarta.

BPS. 2016. Jakarta Dalam Angka Tahun 2016. Badan Pusat Statistik Provinsi DKI Jakarta. Jakarta. 
Gubernur Provinsi Daerah Khusus Ibukota Jakarta. 2007. Surat Keputusan Gubernur Provinsi Daerah Khusus Ibukota Jakarta Nomor 171 Tahun 2007 tentang Luas Wilayah Provinsi DKI Jakarta. Jakarta.

Hidayat, M. A. 2016. Education Center di Surakarta, Jawa Tengah. Skripsi (unpublished). Jurusan Teknik Arsitektur Fakultas Teknik Sipil dan Perencanaan Universitas Gunadarma. Jakarta.

Laurie, M. 1986. Pengantar Kepada Arsitektur Pertamanan (Terjemahan). Intermatra, Bandung.

Putri, M. N. 2013. Perancangan Taman Terapi Hortikultura bagi Penderita Gangguan Jiwa pada Rumah Sakit Jiwa Provinsi Bali. Skripsi (unpublished). Program Studi Arsitektur Pertamana Jurusan Budidaya Pertanian Fakultas Pertanian Universitas Udayana. Denpasar. 